\title{
Skin - a vast organ with immunological function (Review)
}

\author{
MINELA AIDA MARANDUCA ${ }^{1 *}$, LOREDANA LILIANA HURJUI $^{1 *}$, DANIEL CONSTANTIN BRANISTEANU ${ }^{2 *}$, \\ DRAGOMIR NICOLAE SERBAN ${ }^{1}$, DACIANA ELENA BRANISTEANU ${ }^{3}$, \\ NICOLETA DIMA $^{4}$ and IONELA LACRAMIOARA SERBAN ${ }^{1}$
}

\author{
Departments of ${ }^{1}$ Physiology, ${ }^{2}$ Opthalmology, ${ }^{3}$ Dermatology and ${ }^{4}$ Internal Medicine, \\ ‘Grigore T. Popa’ University of Medicine and Pharmacy, 700115 Iasi, Romania
}

Received January 13, 2020; Accepted February 12, 2020

DOI: $10.3892 /$ etm.2020.8619

\begin{abstract}
The skin is an organ with multiple functions, where important inflammatory and immunological processes take place. The integrity of the skin barrier is necessary for it to fulfill its roles. An intact skin barrier requires a physiological keratinization process, but also a normal cutaneous microbial flora. Any change in the proliferation and differentiation of keratinocytes entails the disruption of the skin barrier and the triggering of inflammatory and immunological processes at this level, in response to the aggression of external pathogens. Also, there are several specialised immune cells in the skin (Langerhans cells, $\mathrm{T}$ regulator cells, $\mathrm{T}$ helper cells), that maintain a balance between pro-inflammatory and anti-inflammatory processes at this level. Disturbing the immune homeostasis causes inflammation and allergic skin reaction. Psoriasis and atopic dermatitis are two inflammatory diseases of the skin, characterized by perturbation of the mechanisms of skin barrier formation. The immune system of the skin is also involved in the pathophysiology of vitiligo and pemphigus. The aim of this review is to offer a brief presentation of the inflammatory and immunological processes that occur in the skin.
\end{abstract}

\section{Contents}

1. Introduction

2. Skin barrier formation

3. Immune cells of the skin

4. Inflammatory skin diseases

5. Conclusion

Correspondence to: Professor Dragomir Nicolae Serban, Department of Physiology, 'Grigore T. Popa' University of Medicine and Pharmacy, 16 Universitatii Street, 700115 Iasi, Romania

E-mail: dnserban@yahoo.com

${ }^{*}$ Contributed equally

Key words: skin, barrier, keratinocyte, cytokines, lymphocytes

\section{Introduction}

The skin, which also participates in the hydro-electrolytic balance by limiting water loss, is the largest organ of the human body and it is a general protective barrier against external aggression, but this protection also includes important immunological functions. Thus, protection against external agents, as it is conferred by the tegument, also involves the active and integrated part of the immune system that is present here. The skin's immune system creates a permanent balance between the pro-inflammatory and the anti-inflammatory response. Structural and functional integrity of the skin are imperative conditions for it to be able to fulfill its many roles.

Epidermis, the most superficial layer of the skin, is the skin compartment that provides the barrier function. It consists of 4-5 cell layers (basal layer, cornified layers, granular layer, clear or translucent layer (present only in the skin of the palms and plantar part of the feet), and the spinous layer (1). The epidermis acts as three lines of defense: physical barrier that limits mechanical aggression and penetration of pathogens; chemical barrier, including antimicrobial role; barrier against water and electrolyte loss (2).

Keratinocytes have an essential role in the formation and maintenance of the skin barrier function. These cells traverse all layers of the epidermis. Through a proliferation and differentiation process, in the cornified layer they turn into corneocytes, a process which is under the strict control of cytokines $(3,4)$, produced by keratinocytes and by other resident cells of the skin. The perturbation of the physiological process of keratinocyte differentiation, caused by the disturbance of cytokine gene expression, modifications of the lipid composition of the keratinocyte membrane and corneocyte desquamation defects, lead to altered quality of the skin barrier. Thus, by increasing the permeability of this barrier, a number of substances/microorganisms penetrate the body, which promotes and perpetuates the inflammatory processes at this level and triggers immunological reactions. Defects in skin barrier formation have been observed in a number of inflammatory skin diseases, such as atopic dermatitis (5), psoriasis, ichthyosis and urticaria (6,7).

On the surface of the skin there is also a multitude of commensal bacteria, which form the cutaneous microbiota and which have a role in protection against invasion by pathogens. The skin has a powerful mechanism to repair its integrity 
after traumas or aggression by ultraviolet radiation. This repair function also involves the immune cells present in the skin. Cutaneous homeostasis (8) is maintained by permanent coordination and communication between epithelial cells and immune cells in the skin. Any disruption of the skin microbiota and/or of the skin repair mechanism leads to inflammatory cutaneous processes, to an imbalance between proinflammatory and anti-inflammatory factors and to the occurrence of inflammatory and allergic dermatological diseases. In recent years there has been an increase in autoimmune skin diseases. Autoimmune skin disease affects the immune system and results in autoantibodies, i.e. antibodies against self-antigens. The concept of the immune system of the skin, can be seen like a complex relation between immune cells, epithelial cells, and the external environment.

Epidemiological data show that psoriasis, a significant public health challenge, affects $\sim 125$ million people globally (9). Prevalence estimates within adult populations range from $0.91 \%$ in the USA to $8.5 \%$ in Norway (10). Another autoimmune skin disease, vitiligo affects $\sim 1 \%$ of the general population (11), the risk of a patient's sibling developing the disease is $6 \%$, and for an identical twin it is $23 \%$, while pemphigus is estimated to affect $\sim 0.5-30$ cases per million globally (12).

\section{Skin barrier formation}

The process of keratinization. Cornification or keratinization is the complex process of normal formation of the stratum corneum, through which keratinocytes suffer important morphological and structural changes, eventually transforming into corneocytes. An intact cornified layer is essential for the skin to form an impenetrable barrier (13). Keratinocytes, cells that are permanently restored, undergo mitosis and proliferation in the basal layer. Differentiated and mature keratinocytes, pass through all layers of skin, lose their nuclei and cellular organelles, begin to secrete keratin, and turn into corneocytes in the cornified layer.

During the process, a membrane is formed that surrounds the keratinocytes at the periphery. The membrane is rich in proteins and lipids. The membrane formation process involves the binding of proteins, especially loricrine and involucrine, to keratinocyte filaments, when they transit from the granule layer to the stratum corneum (14). An important role in the stabilization of these proteins is the cross-linking of filagrin. The lipid barrier is located externally from the corneous membrane and is composed especially of ceramides, which bind covalently. The lipid layer limits hydro-electrolytic losses through the epidermis. The dead and flattened corneocytes, united by corneodesmosomes (modified desmosomal structures), form the stratum corneum, which confers resistance to mechanical stimuli.

Old corneocytes are removed from the surface of the epidermis by desquamation. Increasing the calcium concentration in the stratum corneum is the trigger factor of this process. A series of specific proteases that degrade cornodesmozomal proteins are activated, and thus the bonds of the cells of the stratum corneum become unstable and the cells are eliminated. The keratinization process involves a series of enzymatic reactions and is dependent on structural proteins, fatty acids and lipids, whose gene expression and function are controlled by cytokines and intracellular signal molecules. Also, as they differentiate, keratinocytes secrete a series of fatty acids (15) and antimicrobial peptides (RNASE 7, psoriasin and calprotectin) that attach to the lipid membrane (16). Keratinocytes respond to inflammation caused by the pathogenesis of crackles of the skin barrier by catechidyl LL-37 secretion and defensins, two peptides with antimicrobial properties (17).

The keratohyaline granules. The keratohyaline granules are present in the granular layer of the epidermis and contain keratin filaments and proteins associated with these filaments: loricrine, filagrine and tricohyaline $(18,19)$. Depending on location, the keratohyaline granules are either present in the globular form (the oral mucosa epithelium) or in the stellate form (the normal epidermis) (20). These granules are insoluble in water and play an important role in the formation of corneocyte envelope. The keratohyaline granules contain ribosomes that are involved in initiating the formation of intermediate keratin filaments and in the proteins assembling process (20). The granules grow progressively as they move from the spinous layer to the stratum corneum (21) and participate in the homogenization of the keratin matrix (22). Profilagrin, the predominant content of keratohyaline granules, is the protein precursor of filagrin (23). Profilagrin, in the course of epidermal differentiation, turns into free monomers of filagrin, which interact with keratin filaments. The keratohyaline granules have been observed in the thymus medulla, in the cytoplasm of the Hassal corpuscles. They appear to be involved in the development of $\mathrm{T}$ lymphocytes because they produce IL-4 and IL-7 (24).

\section{Immune cells of the skin}

To summarize the overall picture of the skin as an immune organ, as described hereafter, a general scheme is presented in Fig. 1.

Langerhans cutaneous cells. Langerhans cells are antigenpresenting dendritic cells $(25,26)$ that play a role in long-term immunity. They were discovered in 1970 by Ralph Steinman and Zanvil Cohn and are involved in the generation of $\mathrm{CD}^{+}$lymphocytes and in the transformation of $\mathrm{CD}^{+}$ lymphocytes into various cell subtypes (Th1, Th2, Th17) (21). Skin dendritic cells have a protective or suppressive role in skin disorders (27) and are found in the epidermis. These cells have myeloid origin and have characteristics close to monocytes (28). At the skin level, the dendritic cells are inserted between the keratinocytes and create tight junctions with them. When the epidermis is stimulated by mechanical stimuli, Langerhans cells increase the mobility of dendrites. The integrity of the barrier is monitored this way. Moreover, dendritic cells provide immunity without a real infection, against a series of antigens that have not penetrated the cutaneous barrier (29). The presence of important dendritic cells at the skin level makes the skin an important place for vaccination and creation of long-term immunity (30). In atopic dermatitis, skin dendritic cells play a role in the recruitment of eosinophils (31). The lichen may also involve autoimmune aspects $(32,33)$, including an increased $\mathrm{Th} 1 / \mathrm{Th} 2$ ratio. 


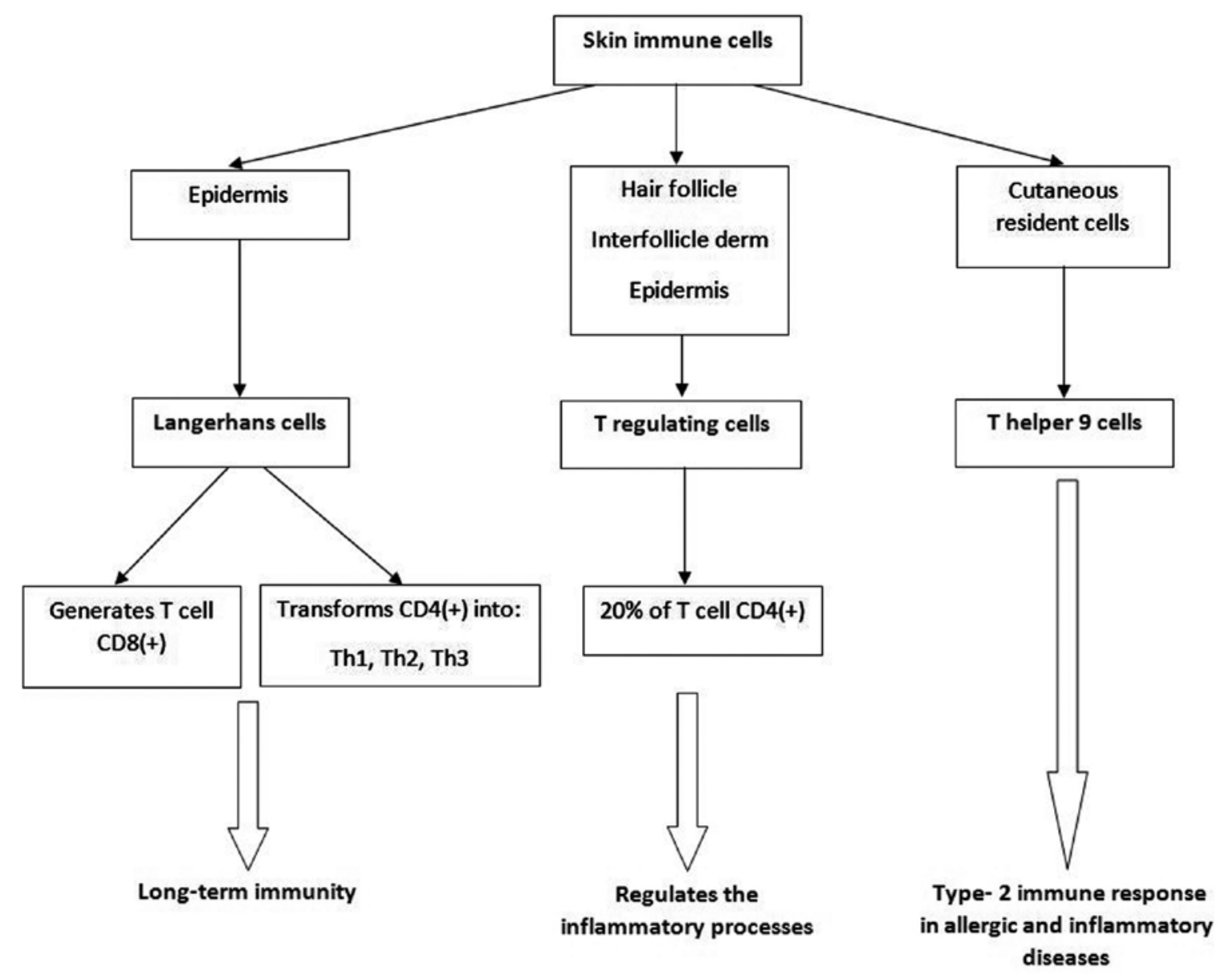

Figure 1. Skin immune cells.

T regulating cells of the skin (Treg). An intact skin barrier also requires the integrity of its attachments: hair follicle, sebaceous glands and sweat glands. Treg cells (34) represent a subset of $\mathrm{CD}^{+}$lymphocytes, which are predominantly found in the hair follicle, especially in regions with high follicular density. They have also been identified, but in small amounts, in the interfollicular dermis and epidermis (35). These represent $20 \%$ of $\mathrm{CD}^{+} \mathrm{T}$ cells in the skin. Treg lymphocytes play a role in maintaining immunological homeostasis of the skin (36) by regulating inflammatory processes at this level. These cells come from either the thymus, after mature T-lymphocytes (they become capable of recognizing their own antigens), or formed from the naive $\mathrm{CD} 4^{+} \mathrm{T}$ lymphocytes with peripheral antigens (37). Treg cells offer protection against skin cancer (38) because they secrete IL-10 and TGF- $\beta$, cytokines that suppress immune response and inflammation (39). Treg cells actively maintain the skin microparticle homeostasis (40), which provides protection against bacterial and parasitic agents, hair follicle regeneration and skin stimulation of cell differentiation processes and mucosal cell regeneration. IL-7 is essential for the normal function of Treg and IL-2 is important for their normal development in the thymus (41).

Thelper 9 (Th9). A subset of IL-9 secreting CD $4^{+}$cells, Th9 lymphocytes are cutaneous resident cells. These, by regulating the synthesis of pro-inflammatory cytokines (42), are involved in triggering the type 2 immune response from allergic and inflammatory diseases (43). In vitro, IL-9 increases the synthesis of IL-8 and vascular endothelial growth factor (VEGF) (44-46).

\section{Inflammatory skin diseases}

Psoriasis - an immune-mediated inflammatory disease. World Health Organization (WHO) has recently stated that psoriasis is a serious, chronic, disfiguring, disabling, noncommunicable disease (47). The WHO report highlights the need for data collection documenting prevalence and incidence of psoriasis in order to estimate accurately the social and economic burden of the disease (48). The etiology of the disease is unclear but genetic and environmental factors (49) are thought to be the reason behind the abnormal immune response in psoriasis patients. Epidemiological studies in psoriasis have reported a significantly increased risk of inflammatory comorbid conditions (50), including psoriatic arthritis, depression, obesity, diabetes, liver disease, metabolic syndrome and cardiovascular disease (CVD).

Psoriasis is a $\mathrm{T}$ cell mediated autoimmune disease, characterized by keratinocyte proliferation, while psoriasin (S100A7) and koebnerisin (S100A15) are proinflammatory proteins that are upregulated in psoriasis and act as chemoattractants for the immune cells. A protein group called antimicrobial peptides (AMP) has been well studied concerning the immune mechanism of psoriasis. They are highly expressed, especially 
cathelicidin, $\beta$-defensins and S100 proteins (51). Psoriasis is a T cell mediated autoimmune disease and it is hypothesized that the effector T cells accumulate in lymph nodes and finally they migrate into the skin via the blood. Moreover, psoriatic skin is shown to be another source for inflammatory $\mathrm{T}$ cells (52). In psoriatic patients various proinflammatory cytokines are in higher plasma concentration, such as IL-6, IL-2, IL-10, IFN- $\gamma$, IL-17 (53), IL-21, IL-22, IL-23, IL-9, while low concentrations were found for IL-4 and IL-27 (54-56).

Vitiligo - immunologic mechanisms. Vitiligo is a common, disfiguring autoimmune disorder that negatively influences patients self-esteem and quality of life. The characteristic of this disease is that epidermal melanocytes are targeted and destroyed in various ways and the consequence is the appearance of irregular depigmentation of the skin. Numerous studies show that melanocytes from vitiligo patients have intrinsic defects that reduce their capacity to manage cellular stress (57). The pathogenic factors of vitiligo include $\mathrm{CD}^{+}$ $\mathrm{T}$ lymphocyte/T helper 1 infiltrates in lesional skin $(58,59)$, with increased expression of IFN- $\gamma(60)$ and tumor necrosis factor- $\alpha$ (61-64), decreased transforming growth factor- $\beta$, and circulating autoantibodies against tyrosine hydroxylase (65). Additionally, several studies have found a high prevalence of antecedent psychological stressors in vitiligo patients, suggesting that specific stressors may trigger or exacerbate vitiligo (66-69). Studies reveal that CXCL16 expression increased and showed a positive correlation with oxidative stress levels in serum and lesions of patients with vitiligo. CXCL16 produced by stressed keratinocytes induced migration of $\mathrm{CXCR}^{+} \mathrm{CD}^{+} \mathrm{T}$ cells derived from patients with vitiligo. $\mathrm{CXCR}^{+} \mathrm{CD}^{+} \mathrm{T}$ cell skin infiltration is accompanied by melanocyte loss in lesions of patients with vitiligo (70). It is assumed that infiltration of the cytotoxic CD8 T cells might be responsible for the melanocyte destruction in vitiligo.

Pemphigus - immunologic network base. Pemphigus and bullous pemphigoid are autoantibody-mediated blistering skin diseases, in which $\operatorname{IgG}$ autoantibodies are produced mainly against autoantigens Desmoglein-1 (DSG1) and Desmoglein-3 (DSG3). In pemphigus the keratinocytes in epidermis and mucous membranes lose cell-cell adhesion, while in pemphigoid the basal keratinocytes lose adhesion to the basement membrane $(71,72)$. Also, in pemphigus patients, activated $\mathrm{B}$ cells act as pathogenic regulators by secreting anti-DSG3 autoantibodies. B regulatory cells (B reg) are able to down regulate immune responses in mice and humans by secreting IL-10, TGF- $\beta$ and expressing FOXP3 $(73,74)$. An early cytokine of Th1 type, osteopontin (OPN), augments production of IFN- $\gamma$, IL-12 and decreases IL-10 production (75). In pemphigus, as in other autoimmune disorders, OPN production is elevated, which indicates a Th1 response (76).

Atopic dermatitis - immune disorder in correlation with microbiota. Atopic dermatitis (AD) is a chronic Th2 type inflammatory skin disease associated with cutaneous hyper-reactivity to environmental triggers (74). A chronic relapsing skin disease, $\mathrm{AD}$ has a characteristic phenotype, with typically distributed skin lesions, that often render its diagnosis very simple and clear-cut (75). Staphylococcus aureus is found in $>90 \%$ of the patients with chronic AD skin lesions (76). Acute exudative skin lesions can contain over 10 million of these organisms per square centimeter, and increased numbers have been found even in normal skin and the nasal vestibula or intertriginous areas of patients with AD. Scratching is an important factor, enhancing the binding of bacteria, by disturbing the skin barrier and exposing extracellular matrix molecules known to act as adhesins for $S$. aureus (fibronectin, collagens, fibrinogen, elastin, laminin) (77). In addition, bacterial binding seems to be higher at skin sites with Th2-mediated inflammation and the respective cytokine medium, due to induction of an enhanced production of these adhesins and downregulation of antimicrobial peptides needed to control the replication of S. aureus $(78,79)$. IgE autoreactivity is an immune pathogenic factor in AD. In addition, molecular analysis of allergens has revealed striking similarities between environmental allergens and human proteins, leading to the hypothesis that autoimmune reactions also might play a role $(80,81)$.

\section{Conclusion}

The skin is important both as barrier and as connection between the environment and the body. It is well known that the skin provides a receptor function, translating to the organism substantial information from the environment, in many different ways. The skin immunological function could be regarded as an extremely multifaceted and intricate interplay between signal processing and the defense reactions. This is further complicated by many autoimmune aspects. The continuous huge progress in immunology clearly impacts our understanding of the immunological function of the skin, with multiple insights to various etyopathogenic entities. This review is an invitation to the wide area of roles and mechanisms involved in the immunology of the healthy and diseased skin.

\section{Acknowledgements}

Not applicable.

\section{Funding}

No funding was received.

\section{Availability of data and materials}

Not applicable.

\section{Authors' contributions}

All the authors substantially contributed to each of the following aspects of this review paper: Conception and design (mainly MAM, LLH, DCB, DNS and ILS) and selection, analysis and interpretation of cited references (all the authors, but mainly MAM, LLH, DCB, DEB and ND). Moreover, all the authors were involved in drafting of the manuscript (mainly MAM, LLH and DCB) and in revising it critically for important intellectual content (mainly DNS, DEB, ND and ILS). All the authors have given their final approval of the version to be published. Thus, each author has participated sufficiently in the 
work and takes public responsibility for appropriate portions of the content, so that the authors agree to be accountable for all aspects of the work in ensuring that questions related to the accuracy or integrity of any part of the work are appropriately investigated and resolved.

\section{Ethics approval and consent to participate}

Not applicable.

\section{Patient consent for publication}

Not applicable.

\section{Competing interests}

The authors declare that they have no competing interests.

\section{References}

1. Maranduca MA, Branisteanu D, Serban DN, Branisteanu DC Stoleriu G, Manolache N and Serban IL: Synthesis and physiological implications of melanic pigments. Oncol Lett 17: 4183-4187, 2019.

2. Hänel KH, Cornelissen C, Lüscher B and Baron JM: Cytokines and the skin barrier. Int J Mol Sci 14: 6720-6745, 2013.

3. Ilie MA, Caruntu C, Tampa M, Georgescu SR, Matei C, Negrei C, Ion RM, Constantin C, Neagu M and Boda D: Capsaicin: Physicochemical properties, cutaneous reactions and potential applications in painful and inflammatory conditions. Exp Ther Med 18: 916-925, 2019.

4. Branisteanu D, Caruntu C, Negrei C, Ghita MA, Caruntu A, Badarau AI, Buraga I, Boda D and Albu A: Capsaicin, a hot topic in skin pharmacology and physiology. Farmacia 63: 487-491, 2015.

5. Căruntu C, Boda D, Musat S, Căruntu A and Mandache E: Stress-induced mast cell activation in glabrous and hairy skin. Mediators Inflamm 2014: 105950, 2014.

6. Guttman-Yassky E, Nograles KE and Krueger JG: Contrasting pathogenesis of atopic dermatitis and psoriasis - part I: Clinical and pathologic concepts. J Allergy Clin Immunol 127: 1110-1118, 2011.

7. Caruntu C, Boda D, Musat S, Caruntu A, Poenaru E, Calenic B, Savulescu-Fiedler I, Draghia A, Rotaru M and Badarau AI: Stress effects on cutaneous nociceptive nerve fibers and their neurons of origin in rats. Rom Biotechnol Lett 19: 9517-9530, 2014.

8. Lupu M, Caruntu A, Caruntu C, Papagheorghe LML, Ilie MA, Voiculescu V, Boda D, Constantin C, Tanase C, Sifaki M, et al: Neuroendocrine factors: The missing link in non melanoma skin cancer (Review). Oncol Rep 38: 1327-1340, 2017.

9. International Federation of Psoriasis Associations: World Psoriasis Day, 2015. Available at: https://ifpa-pso.com/2015/10/29/ press-world-psoriasis-day-2015-brings-hope.

10. Parisi R, Symmons DP, Griffiths CE and Ashcroft DM Identification and Management of Psoriasis and Associated ComorbidiTy (IMPACT) project team: Global epidemiology of psoriasis: A systematic review of incidence and prevalence. J Invest Dermatol 133: 377-385, 2013.

11. Taïeb A and Picardo M: Clinical practice. Vitiligo. N Engl J Med 360: 160-169, 2009.

12. Alkhateeb A, Fain PR, Thody A, Bennett DC and Spritz RA: Epidemiology of vitiligo and associated autoimmune diseases in Caucasian probands and their families. Pigment Cell Res 16 : 208-214, 2003.

13. Proksch E, Brandner JM and Jensen JM: The skin: An indispensable barrier. Exp Dermatol 17: 1063-1072, 2008.

14. Freeman SC and Sonthalia S: Histology, Keratohyalin Granules. StatPearls Publishing, Treasure Island, FL, 2019.

15. Harder J, Schröder JM and Gläser R: The skin surface as antimicrobial barrier: Present concepts and future outlooks. Exp Dermatol 22: 1-5, 2013.

16. Gallo RL and Hooper LV: Epithelial antimicrobial defence of the skin and intestine. Nat Rev Immunol 12: 503-516, 2012.
17. Manabe M and O'Guin WM: Keratohyalin, trichohyalin and keratohyalin-trichohyalin hybrid granules: An overview. J Dermatol 19: 749-755, 1992

18. Nithya S, Radhika T and Jeddy N: Loricrin - an overview. J Oral Maxillofac Pathol 19: 64-68, 2015.

19. Westerhof W and Dingemans KP: The morphology of keratohyalin granules in orthokeratotic and parakeratotic skin and oral mucosa. Int J Dermatol 26: 308-313, 1987.

20. Yousef H, Alhajj M and Sharma S: Anatomy, Skin (Integument), Epidermis. StatPearls Publishing, Treasure Island, FL, 2019.

21. Westerhof W and Dingemans KP: The morphological details of globular keratohyalin granules. J Cutan Pathol 13: 375-382, 1986.

22. Dinh MH, McRaven MD, Kelley Z, Penugonda S and Hope TJ: Keratinization of the adult male foreskin and implications for male circumcision. AIDS 24: 899-906, 2010.

23. Takahashi M,Horiuchi Y and Tezuka T: Hematoxylin-stainability of keratohyalin granules is due to the novel component, fibrinogen $\gamma$-chain protein. Arch Dermatol Res 302: 679-684, 2010.

24. Fukuyama K and Epstein WL: Heterogeneous ultrastructure of keratohyalin granules: A comparative study of adjacent skin and mucous membrane. J Invest Dermatol 61: 94-100, 1973.

25. Nwabudike LC, Elisei AM, Buzia OD, Miulescu M and Tatu AL: Statins: A review on structural perspectives, adverse reactions and relations with non-melanoma skin cancer. Rev Chim Buchar 69: 2557-2562, 2018.

26. Cioplea M, Caruntu C, Zurac S,Bastian A, Sticlaru L, Cioroianu A Boda D, Jugulete G, Nichita L and Popp C: Dendritic cell distribution in mycosis fungoides vs. inflammatory dermatosis and other T-cell skin lymphoma. Oncol Lett 17: 4055-4059, 2019.

27. Steinman RM and Cohn ZA: Identification of a novel cell type in peripheral lymphoid organs of mice. I. Morphology, quantitation, tissue distribution. J Exp Med 137: 1142-1162, 1973.

28. Rajesh A, Wise L and Hibma M: The role of Langerhans cells in pathologies of the skin. Immunol Cell Biol 97: 700-713, 2019.

29. Nirschl CJ and Anandasabapathy N: Duality at the gate: Skin dendritic cells as mediators of vaccine immunity and tolerance. Hum Vaccin Immunother 12: 104-116, 2016.

30. Teunissen MBM, Haniffa M and Collin MP: Insight into the immunobiology of human skin and functional specialization of skin dendritic cell subsets to innovate intradermal vaccination design. Curr Top Microbiol Immunol 351: 25-76, 2012.

31. Scharschmidt TC, Vasquez KS, Pauli ML, Leitner EG, Chu K, Truong HA, Lowe MM, Sanchez Rodriguez R, Ali N, Laszik ZG, et al: Commensal microbes and hair follicle morphogenesis coordinately drive treg migration into neonatal skin. Cell Host Microbe 21: 467-477.e5, 2017.

32. Brănişteanu DE, Pintilie A, Andreş LE, Dimitriu A, Oanţă A, Stoleriu G and Brănişteanu DC: Ethiopatogenic hypotheses in lichen planus. Rev Med Chir Soc Med Nat Iasi 120: 760-767, 2016.

33. Brănişteanu DE, Brănişteanu DC, Stoleriu G, Ferariu D, Voicu CM, Stoica LE, Căruntu C, Boda D, Filip-Ciubotaru FM, Dimitriu A, et al: Histopathological and clinical traps in lichen sclerosus: A case report. Rom J Morphol Embryol 57 (Suppl 2): 817-823, 2016.

34. Sakaguchi S, Yamaguchi T, Nomura T and Ono M: Regulatory T cells and immune tolerance. Cell 133: 775-787, 2008.

35. Tang $\mathrm{L}$ and Wang $\mathrm{K}$ : Chronic inflammation in skin malignancies. J Mol Signal 11: 2, 2016.

36. Suwanpradid J, Holcomb ZE and MacLeod AS: Emerging skin T-cell functions in response to environmental insults. J Invest Dermatol 137: 288-294, 2017.

37. Ali $\mathrm{N}$ and Rosenblum MD: Regulatory $\mathrm{T}$ cells in skin. Immunology 152: 372-381, 2017.

38. Boda D: Cellomics as integrative omics for cancer. Curr Proteomics 10: 237-245, 2013.

39. Sakaguchi S, Vignali DA, Rudensky AY, Niec RE and Waldmann $\mathrm{H}$ : The plasticity and stability of regulatory $\mathrm{T}$ cells. Nat Rev Immunol 13: 461-467, 2013.

40. Schlapbach C, Gehad A, Yang C, Watanabe R, Guenova E, Teague JE, Campbell L, Yawalkar N, Kupper TS and Clark RA: Human TH9 cells are skin-tropic and have autocrine and paracrine proinflammatory capacity. Sci Transl Med 6: 219ra8, 2014.

41. Kaplan MH, Hufford MM and Olson MR: The development and in vivo function of T helper 9 cells. Nat Rev Immunol 15: 295-307, 2015.

42. Liu J,Harberts E, Tammaro A, Girardi N, Filler RB, Fishelevich R, Temann A, Licona-Limón P, Girardi M, Flavell RA, et al: IL-9 regulates allergen-specific Th1 responses in allergic contact dermatitis. J Invest Dermatol 134: 1903-1911, 2014. 
43. Ma L, Xue HB, Guan XH, Shu CM, Zhang JH and Yu J: Possible pathogenic role of T helper type 9 cells and interleukin (IL)-9 in atopic dermatitis. Clin Exp Immunol 175: 25-31, 2014.

44. World Health Organization: Global report on psoriasis. World Health Organization, Geneva, 2016, ISBN 9789241565189. Available at: https://apps.who.int/iris/handle/10665/204417.

45. Gelfand JM, Neimann AL, Shin DB, Wang X, Margolis DJ and Troxel AB: Risk of myocardial infarction in patients with psoriasis. JAMA 296: 1735-1741, 2006.

46. Solomon I, Voiculescu VM, Caruntu C, Lupu M, Popa A Ilie MA, Albulescu R, Caruntu A, Tanase C, Constantin C, et al Neuroendocrine factors and head and neck squamous cell carcinoma: An affair to remember. Dis Markers 2018: 9787831 , 2018.

47. Batycka-Baran A, Maj J, Wolf R and Szepietowski JC: The new insight into the role of antimicrobial proteins-alarmins in the immunopathogenesis of psoriasis. J Immunol Res 2014: 628289, 2014.

48. Dunphy SE, Sweeney CM, Kelly G, Tobin AM, Kirby B and Gardiner CM: Natural killer cells from psoriasis vulgaris patients have reduced levels of cytotoxicity associated degranulation and cytokine production. Clin Immunol 177: 43-49, 2017.

49. Grigore O, Mihailescu AI, Solomon I, Boda D and Caruntu C: Role of stress in modulation of skin neurogenic inflammation. Exp Ther Med 17: 997-1003, 2019.

50. Witte E, Kokolakis G, Witte K, Philipp S, Doecke WD, Babel N, Wittig BM, Warszawska K, Kurek A, Erdmann-Keding M, et al IL-19 is a component of the pathogenetic IL-23/IL-17 cascade in psoriasis. J Invest Dermatol 134: 2757-2767, 2014

51. Nograles KE, Zaba LC, Guttman-Yassky E, Fuentes-Duculan J, Suárez-Fariñas M, Cardinale I, Khatcherian A, Gonzalez J, Pierson KC, White TR, et al: Th17 cytokines interleukin (IL)-17 and IL-22 modulate distinct inflammatory and keratinocyte-response pathways. Br J Dermatol 159: 1092-1102, 2008.

52. Chen W, Gong $Y$, Zhang $X$, Tong $Y$, Wang $X$, Fei C, Xu H, Yu Q, Wang Y and Shi Y: Decreased expression of IL-27 in moderate-to-severe psoriasis and its anti-inflammation role in imiquimod-induced psoriasis-like mouse model. J Dermatol Sci 85: 115-123, 2017.

53. Caruntu C, Boda D, Dumitrascu G, Constantin C and Neagu M: Proteomics focusing on immune markers in psoriatic arthritis. Biomarkers Med 9: 513-528, 2015.

54. Harris JE: Cellular stress and innate inflammation in organ-specific autoimmunity: Lessons learned from vitiligo. Immunol Rev 269: $11-25,2016$

55. Goronzy $\mathrm{J}$, Weyand $\mathrm{CM}$ and Waase I: T cell subpopulations in inflammatory bowel disease: Evidence for a defective induction of $\mathrm{T}^{+}$suppressor/cytotoxic T lymphocytes. Clin Exp Immunol 61: 593-600, 1985

56. Ongenae K, Van Geel N and Naeyaert JM: Evidence for an autoimmune pathogenesis of vitiligo. Pigment Cell Res 16: 90-100, 2003.

57. Grimes PE, Morris R, Avaniss-Aghajani E, Soriano T, Meraz M and Metzger A: Topical tacrolimus therapy for vitiligo: Therapeutic responses and skin messenger RNA expression of proinflammatory cytokines. J Am Acad Dermatol 51: 52-61, 2004

58. Birol A, Kisa U, Kurtipek GS, Kara F, Kocak M, Erkek E and Caglayan O: Increased tumor necrosis factor alpha (TNF-alpha) and interleukin 1 alpha (IL1-alpha) levels in the lesional skin of patients with nonsegmental vitiligo. Int J Dermatol 45: 992-993, 2006.

59. Moretti S, Spallanzani A, Amato L, Hautmann G, Gallerani I, Fabiani $\mathrm{M}$ and Fabbri P: New insights into the pathogenesis of vitiligo: Imbalance of epidermal cytokines at sites of lesions. Pigment Cell Res 15: 87-92, 2002.

60. Zailaie MZ: Decreased proinflammatory cytokine production by peripheral blood mononuclear cells from vitiligo patients following aspirin treatment. Saudi Med J 26: 799-805, 2005.
61. Basak PY, Adiloglu AK, Ceyhan AM, Tas T and Akkaya VB: The role of helper and regulatory $\mathrm{T}$ cells in the pathogenesis of vitiligo. J Am Acad Dermatol 60: 256-260, 2009.

62. Kemp EH, Emhemad S, Akhtar S, Watson PF, Gawkrodger DJ and Weetman AP: Autoantibodies against tyrosine hydroxylase in patients with non-segmental (generalised) vitiligo. Exp Dermatol 20: 35-40, 2011.

63. Barisić-Drusko V and Rucević I: Trigger factors in childhood psoriasis and vitiligo. Coll Antropol 28: 277-285, 2004.

64. Manolache L and Benea V: Stress in patients with alopecia areata and vitiligo. J Eur Acad Dermatol Venereol 21: 921-928, 2007.

65. Papadopoulos L, Bor R, Legg C and Hawk JL: Impact of life events on the onset of vitiligo in adults: Preliminary evidence for a psychological dimension in aetiology. Clin Exp Dermatol 23: 243-248, 1998.

66. Picardi A, Pasquini P, Cattaruzza MS, Gaetano P, Melchi CF, Baliva G, Camaioni D, Tiago A, Abeni D and Biondi M: Stressful life events, social support, attachment security and alexithymia in vitiligo. A case-control study. Psychother Psychosom 72 $150-158,2003$

67. Li S, Zhu G, Yang Y, Jian Z, Guo S, Dai W, Shi Q, Ge R, Ma J, Liu L, et al: Oxidative stress drives $\mathrm{CD}^{+} \mathrm{T}$-cell skin trafficking in patients with vitiligo through CXCL16 upregulation by activating the unfolded protein response in keratinocytes. J Allergy Clin Immunol 140: 177-189.e9, 2017.

68. Kasperkiewicz M, Ellebrecht CT, Takahashi H, Yamagami J, Zillikens D, Payne AS and Amagai M: Pemphigus. Nat Rev Dis Primers 3: 17026, 2017.

69. Pollmann R, Schmidt T, Eming R and Hertl M: Pemphigus: A comprehensive review on pathogenesis, clinical presentation and novel therapeutic approaches. Clin Rev Allergy Immunol 54: $1-25,2018$.

70. Fujimoto M: Regulatory B cells in skin and connective tissue diseases. J Dermatol Sci 60: 1-7, 2010.

71. Mauri C and Bosma A: Immune regulatory function of B cells. Annu Rev Immunol 30: 221-241, 2012

72. Inoue M and Shinohara ML: Intracellular osteopontin (iOPN) and immunity. Immunol Res 49: 160-172, 2011.

73. Baroni A, De Filippis A, Buommino E, Satriano RA and Cozza V: Osteopontin, a protein with cytokine-like properties: A possible involvement in pemphigus vulgaris. Arch Dermatol Res 304: 237-240, 2012.

74. Leung DY and Bieber T: Atopic dermatitis. Lancet 361: 151-160, 2003.

75. Spergel JM and Paller AS: Atopic dermatitis and the atopic march. J Allergy Clin Immunol 112 (Suppl): S118-S127, 2003.

76. Leung DY: Infection in atopic dermatitis. Curr Opin Pediatr 15: 399-404, 2003

77. Cho SH, Strickland I, Boguniewicz M and Leung DY: Fibronectin and fibrinogen contribute to the enhanced binding of Staphylococcus aureus to atopic skin. J Allergy Clin Immunol 108: 269-274, 2001.

78. Gallo RL, Murakami M, Ohtake T and Zaiou M: Biology and clinical relevance of naturally occurring antimicrobial peptides. J Allergy Clin Immunol 110: 823-831, 2002.

79. Ong PY, Ohtake T, Brandt C, Strickland I, Boguniewicz M, Ganz T, Gallo RL and Leung DY: Endogenous antimicrobial peptides and skin infections in atopic dermatitis. N Engl J Med 347: 1151-1160, 2002.

80. Ochs RL,Muro Y,Si Y,GeH,Chan EK and Tan EM: Autoantibodies to DFS $70 \mathrm{kd} /$ transcription coactivator $\mathrm{p} 75$ in atopic dermatitis and other conditions. J Allergy Clin Immunol 105: 1211-1220, 2000.

81. Seiberler S, Natter S, Hufnagl P, Binder BR and Valenta R: Characterization of IgE-reactive autoantigens in atopic dermatitis. 2 . A pilot study on IgE versus IgG subclass response and seasonal variation of IgE autoreactivity. Int Arch Allergy Immunol 120: 117-125, 1999. 